\title{
Liberation reimagined: Counter imperial theology and the gospel
}

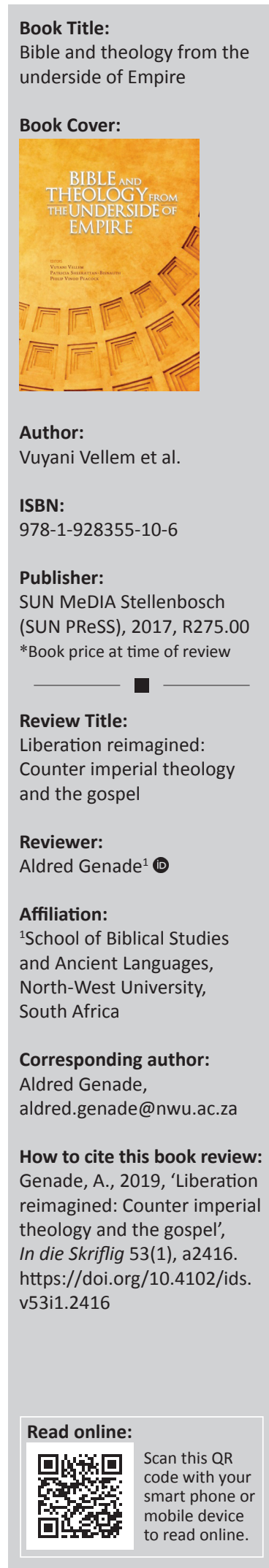

Set against the backdrop of John 10:10, the contributors who hail from Asia, the Caribbean, Zambia, South Africa and the United States, hypothesise that fullness of life, as expressed by Jesus, is the end goal of the mission of the church in the context of Empire. With this being the launchpad, the objective with virtually each article is to highlight not only despair against the dark decor of empire-oppression, but most importantly to brandish hope as the ultimate overcoming offensive in the struggle with Empire.

This compilation of articles aims to reimagine the possibilities of liberation or counter imperial theology. It aims to be: 'A starting point towards liberating broken bodies, colonised spaces and the transgressive expressions of sexuality through the living gospel of Jesus Christ that promises life in its fullness' (p. 223).

The following nouns etch the tone of this work: struggle, revolt, challenge, a rebellion, opposition and subversion. Nearly each of the 18 articles that comprise this publication, contains at least one of them.

The publication offers a reinterpretation of the church's understanding of mission amidst a hostile empire. Empire describes an amalgamation of economic, cultural, political and military forces bent on domination, subservience, exploitation and enslavement of the marginalised masses (p. 5). The self-disclosed purpose of the book is 'to enable faith communities to witness relevantly, subversively and insurrectionally against Empire' (p. 21). It is, however, questionable whether this objective is attainable given the complexities that characterise our contemporary world.

The 18 articles are categorised under the following three topics: broken bodies, colonised spaces and transgressive bodies.

The perhaps ambitious outcome of this book is to offer audiences a global Bible and theological study book (p. 21). However, the hybrid and intentionally diverse nature of the content might hamstring that lofty ambition.

An innovation put forward by the authors is the 'non-conventional hermeneutical exploration' (p. 21). The article 'Sea of creation' by Jione Havea is the first example of this novel hermeneutic (p. 99). It looks at the creation narrative of the first five days in the Genesis record, utilising the Pasifika word talanoa [storytelling, conversation] as the interpretative lens. The conclusions or speculations may leave some more conservative interpreters less inclined to embrace 'nonconventional' hermeneutics (pp. 102; 99-108). The next example - an interesting interpretative angle on the book of Daniel, specifically the furnace incident - is applied to global corporations and branding (p. 19).

Practical theologians and/or their students may find the poignant though tragic story about child sex slavery, as told by a young girl rescued from that environment, insightful (p. 93).

Researchers, focusing on a theology of the body and homophobia within patriarchal heterosexual religious systems, will find the section entitled 'Transgressive bodies' a source of engaging reading. All three articles offer re-interpretative readings of relevant portions from specifically Genesis and Judges (p. 24).

The book succeeds in encouraging a 'subversive', even an 'offensive' mindset with reference to Empire. It stimulates the reader to engage the Empire critically and to pursue redemption in the midst of and in spite of oppressive manifestations of Empire. There is hope, although

Copyright: @ 2019. The Authors. Licensee: AOSIS. This work is licensed under the Creative Commons Attribution License. 
some readers may find the exegetical novelties challenging to digest.

The book is of value for students of ethics and human rights studies, but not limited to the domain of theology. Pastors, theological educators and academics in biblical and theological studies will find value in this book. It is unlikely that 'members of the congregations' would form part of the target consumers of this collection. No doubt they may enjoy the poems, prayers and stories generously sprinkled throughout this book, but the level of engagement is generally more academic than popular. 